\title{
Pavol Dancák
}

University of Prešov, Slovak Republic

(D) https://orcid.org/0000-0002-8067-5651

\section{Contemporary Reflection on Participation as an Essential Dimension of Philosophy of Education in the Context of The Acting Person}

\begin{abstract}
This article considers the problem of the idea of participation as an essential dimension of philosophy of education in the context of Karol Wojtyła's teachings. It proceeds through the concepts of the person and participation. The paper reflects the need for discussion on philosophy of education due to the treatment of individual freedom in an extremely individualistic way. Wojtyła draws on the philosophies of consciousness and the philosophies of being in order to consider the constitution of our ideas in a manner relevant to the education for being together with all people and creatures, with the universe, with the whole world which gives us our own place.
\end{abstract}

Keywords: individualism, person, participation, solidarity, education

\section{Introduction}

At the beginning of the paper I will briefly outline the need for discussion on participation in light of the philosophy of education. Then, I will proceed to Karol Wojtyła's reflexion of man and, in the end, I will introduce participation as communio personarum.

If I were asked why it is important to talk about participation in the philosophy of education, I would quote the report published 16 years ago in 
The Economist. The British magazine wondered whether American business schools that educate future managers in fact harmed the business. The magazine paraphrased the view of Professor Sumantra Ghoshal of the London Business School: Students from these schools learn that managers need not to be trusted - that is, when they become managers themselves, their behavior is untrustworthy. Students were liberated from any sense of moral responsibility. This results in scandals like in Enron, where prominent managers were graduates from such schools. ${ }^{1}$ Truth is that some business schools really seem to be training managers who lack ethics and neglect the social dimension of their job.

Education crisis can be considered in various aspects and many of its causes can be found. A harmful impact of relativism on the educational system is introduced, among others, by teachers' identity disorder, reducing all education subjects to the unilateral dimension of homo oeconomicus, promoting self-care and self-interest to the rank of a moral principle, treating individual freedom in an extremely individualistic way. ${ }^{2}$ According to Czech philosopher of education Radim Palous ${ }^{3}{ }^{3}$ affectionate being together is important because being together with all creatures, with the universe, with the whole world provides us our own place. ${ }^{4}$ Philosopher Charles Taylor describes the degrading of contemporary culture and today's society, pointing to, among other causes, individualism. The consequence of individualism is the emergence of a permissive society, a generation of narcissistic egoists, enclosed in a circle of their own loneliness, the disappearance of the community dimension of life, social horizons of action, common goals and moral responsibility. Individualism, according to Taylor, through the degeneration of moral horizons has led to a situation where everyone has their own morality, in which social rites and norms are limited to their purely instrumental role, any social hierarchies have been discredited, and people have thus lost a sense of a higher purpose, a broader vision of reality, remaining, instead, focused on their own individual lives. ${ }^{5}$ Taylor proposed that we view worrying aspects of modernity, like peoples' obsessive quest for self-

1 "Bad for business?" The Economist, February 19, 2005, https://www.economist.com/ business/2005/02/17/bad-for-business.

${ }^{2}$ Michal Valčo, "Veda vs. scientizmus: kritické postrehy," in Disputationes Quodlibetales XXII. Racionalita a viera, ed. Pavol Dancák and Radovan Šoltés (Prešov: Gréckokatolícka teologická fakulta, 2019), 19-33.

${ }^{3}$ Radim Palouš (1924-2015) was a Czech dissident, a philosopher of education, and former spokesman for Charter 77, and from 1990 to 1994, he was the rector of Charles University in Prague. Palouš was a member of Pontifical Council for Culture. He published over 300 works: the books included The School of the Old Age, Time for Education, Age of the World, Letters to the Godson, The Czech Experience, Persona and Communication, Totalitarianism and Holism, Ars Docendi, etc.

${ }^{4}$ Radim Palouš, K filozofii výchovy (Praha: SPN, 1991), 10.

${ }^{5}$ Charles Taylor, Sources of the Self: The Making of Modern Identity (Cambridge, MA: Harvard University Press, 1992). 
fulfillment, in a different context, namely, not as a forgetfulness of morality but as a degeneration of a genuine moral ideal. ${ }^{6}$

Wojtyła says that individualism sees in the individual the supreme and fundamental good, to which all interests of the community or the society have to be subordinated. Individualism isolates the person from others as an individual who concentrates on himself and on his own goods. ${ }^{7}$ As priority is given to individual goods, individualism also considers community goods as a threat to the individual. Other people are sources of limitation and ultimately present a conflict. Individualism is merely focused on individuals who are acting on their own. In this setup, there is no sense of fulfillment to be found in forming a community where people can experience themselves by acting together with others. People are described to be egoistic because their only concern is their own good. The community is not there to help them out but, rather, it is only there to get in the way of what an individual being wants. The individualist mindset has a narrow and short perspective on the world and on oneself.

Individualism isolates the person from the community and conceives the person solely as the one who concentrates on the pursuit of his own good. Primary individual goods include self-preservation and self-defense from others. Wojtyła adds that from the point of view of individualism, to act "together with others," just as to exist "together with others," is a necessity that the individual must submit to, a necessity that corresponds to none of his very own features or positive properties; neither does the acting and existing with others serve or develop any individual's positive and essential constituents. ${ }^{8}$

One of the problems addressed by Wojtyła is that of alienation. Drawn from the Marxist paradigm, alienation refers to the separation of things that naturally belong together. ${ }^{9}$ In ordinary terms, alienation means being separated from something that one rightfully has ownership of. For example, a person may be alienated from his private property by the virtue of some law or some event. For Wojtyła, alienation is a problem and a hindrance to a person's fulfillment through his actions. Alienation is not a threat to man as a human being but it is a threat to him as a person.

Wojtyła's answer to the problem of alienation is his theory of participation-described as a property of the person as well as an ability to share in the humanity of others. This affirms the fact that man exists and acts together

${ }^{6}$ Charles Taylor, The Ethics of Authenticity (Cambridge, MA: Harvard University Press, 1992).

${ }^{7}$ Karol Wojtyła, The Acting Person, trans. by Andrej Potocki (Dordrecht: D. Reidel Publishing Company, 1979), 271.

8 Wojtyła, The Acting Person, 272.

9 Jarosław Merecki, Osoba i dobro. Szkice o filozofii i teologii osoby Karola Wojtyty - Jana Pavla II (Lublin: Wydawnictwo KUL, 2019), 68. 
with others. He is a member of a community in the form of an "I-you" and a "we" relationship. It consequently means that the constant challenge to seek and to find answers to the issues regarding one's personhood and one's world is a task common to each person that can also be taken as a task of the entire community.

\section{Man-The Person in Action}

Philosophical way of Karol Wojtyła is based on two streams within European philosophy which have different approaches towards reality. The first direction is classical philosophy in the Aristotle-Tomistic understanding or the philosophy of being, (i.e., realistic and objective). The second direction of the European philosophy is the philosophy of modern times (i.e., post-Cartesian), the philosophy of consciousness and subject which follows the Socratic and Augustinian tradition. In his study, Wojtyła uses a phenomenological method but he modifies Husserl's famous motto on returning to things into returning to man as a person. Wojtyła accepts that the traditional, non-phenomenological point of departure of anthropology objectifies man; his own point of departure is a phenomenological description of experience. While Wojtyła objects the cosmological point of departure as inadequate in anthropology, he does not limit anthropology to phenomenology and thus points to a transphenomenological approach to a complete anthropology. Wojtyła rejects Husserl's idealistic turn, which leads to a subjectivist reflection and absolutization of consciousness. ${ }^{10}$ Thanks to phenomenology, we can come to better understanding of the human being as a personal subject and a "somebody" rather than "something." Wojtyła realizes this modification with an intention to objectivize a problem of the subjectivity of man, ${ }^{11}$ so he wants to look at man as a subject capable of knowing, free acting and loving, that is, who lives in participation.

We can see many definitions of man throughout the history of philosophy. Classic definition put forth by Aristotle says that man is anima rationale (a rational animal), where animal stands for what is common and rationale

${ }^{10}$ Rocco Buttiglione, Karol Wojtyla: The Thought of the Man Who Became Pope John Paul II (Grand Rapids, MI: Wm. B. Eerdmans Publishing Co., 1997), 331. Cf. Hans Köchler, "The Phenomenology of Karol Wojtyła. On the Problem of the Phenomenological Foundation of Anthropology," Philosophy and Phenomenological Research, vol. 42 (1982): 326-334.

${ }^{11}$ Karol Wojtyła, "Subjectivity and the Irreducible in Man," in Analecta Husserliana. The Yearbook of Phenomenological Research, vol. VII, 1978, edited by Anna-Teresa Tymieniecka, Reidel Publ., 107. 
for what is different. Wojtyła observes that although this definition answers the Aristotelian definition of kind, species, and species difference, he emphasizes that this definition tacitly assumes reducing a man to a mere part of the world and does not take into consideration what is "irreducible" in man. In this way, man has become predominantly an object and hence one of the many objects of this world where we belong in, visibly and physically. This definition was convenient to classical philosophy which was arising from metaphysics and cosmology; however, Wojtyła points out that man is a subject, that he or she is more than what is expressed in Aristotle's definition. Man cannot be reduced in his own essence or be explained without the rest through kind, species, or species differences. The thing that is irreducible is subjectivity. ${ }^{12}$ Wojtyła tries to look at subjectivity of man objectively in order to avoid subjectivism and thus makes references to a definition by Boethius who defined person as rationalis naturae individua substantia. There, man is perceived as an individual substantial being that has rational nature and in this definition Wojtyła sees something like "metaphysical ground;" in other words, the dimension of being in which man's personal subjectivity is fulfilled. ${ }^{13}$ This metaphysical anchor enables the self to subsist through all the tempests on the sea of experience. ${ }^{14}$ Wojtyła presents a view of the human person that is very much person-centered and based upon individual experiences of self, while maintaining that being (the suppositum) of the person pre-exists any experience.

According to Karol Wojtyła, my "I" confronting your "you" does not aim at possessing "you." "I" treats "you" as a value so that "I" is opening to "you" in order to accept and enrich it, as it concerns the affirmation of man due to the fact that he is man. ${ }^{15}$ The attitude of John Paul II concerning the I-you relation is different from Husserl's and dialogic attitude [...]. According to the philosophers of dialogue, Buber in particular, the first is the relation between "I" and "you." However, according to Wojtyła, existentially the strongest are the personal entities in a basic reality. The I-you relation is secondary towards them, despite the fact that it is significant for them because it strengthens them and participates in the crystallization of their personal entity. ${ }^{16}$

${ }^{12}$ Both the metaphysical-cosmological and the personal-phenomenological methods are necessary to take into account the full richness of the human person. Angela Franz Franks, "Thinking the Embodied Person with Karol Wojtyła," Nova et Vetera, English Edition, vol. 16, no. 1 (2018): 156.

13 Wojtyła, "Subjectivity and the Irreducible in Man," 110.

${ }^{14}$ Franks, "Thinking the Embodied Person," 151.

15 Jove Jim S. Aguas, "Karol Wojtyła: On Person and Subjectivity," Ad Veritatem, vol. 8, no. 2 (2009): 430. Cf. Alfred Wilder, "Community of Person in the Thought of Karol Wojtyła," Angelicum, vol. 56 (1979): 222-223.

16 Sylwia Górzna, "Martin Buber: Father of the Philosophy of Dialogue," European Journal of Science and Theology, vol. 10, no. 5 (2014): 50. 
Karol Wojtyła chooses experience of man to be the premise for his philosophical interest, ${ }^{17}$ whereas he considers the experience of acting to be the fundamental experience, as far as man expresses himself as man in an act, and so the reflection of an act is, according to him, the key to know the truth about man. ${ }^{18}$ Acts form a special moment of revelation and experience of a person. In a certain way they represent the most suitable point of departure in order to understand its dynamic essence.

In the analysis of mans' subjectivity which reveals itself in an action, Wojtyła draws on the experience of man with himself. Experience is always an experience of something (an object), in this case, it is a man. But a man, who has such experience, is subject as well. A man who experiences himself is a subject and an object at the same time. ${ }^{19}$ In experience man has with himself, Wojtyła differentiates active and passive form (agere and pati), that is, he sees a difference in what man does and what happens to him. Active dynamism includes all deliberate and free acts of man. He claims that classical philosophy of Aristotle differentiates between these two kinds of dynamism, but in spite of this, it does not express the dynamics of being in a precise way, because if man acts (agere), at the same time, something happens inside him, so it does not take into consideration subjectivity. ${ }^{20}$

Classical philosophy saw the nature of man not only in animal rationale but it also took social character of man into account. Wojtyła takes over this motif as well, but he also makes a correction, as for him, man is not an inhabitant of polis in the first place, but it is the person who is building relationships with you and we by his acts. According to Wojtyła, to be social means to be open to each other. Personal "I" was defined as a subject which - is capable of realizing himself and as far as he disposes his own will he is able to decide for himself; and so it emphasizes that personal "I" owns itself. It is evident that "I" cannot have the experience of realizing oneself, auto- determination and owning oneself, as they are qualities that are typical of "you," that is, of somebody else. The impossibility of such experience does not mean that it is impossible to understand. ${ }^{21}$ It follows that the scheme "I-the other one" is not general and abstract, but "the other one" always represents real, individual, and irreproducible person.

${ }^{17}$ Wojtyła, The Acting Person, 3.

18 Tadeusz Styczeń, "Być sobą to przekraczać siebie. O antropologii Karola Wojtyły," in Osoba i czyn oraz inne studia antropologiczne (Lublin: TN KUL, 1994), 493.

19 Karol Wojtyła, "The Person: Subject and Community," in The Review of Metaphysics, vol. 33, no. 2 (December 1979): 273-308.

${ }^{20}$ Karol Wojtyła, "Subjectivity and the Irreducible in Man," in Analecta Husserliana. The Yearbook of Phenomenological Research, 110.

${ }^{21}$ Karol Wojtyła, "Participation or Alienation?" in Analecta Husserliana. The Yearbook of Phenomenological Research, vol. 6, 1977, Springer, Dordrecht. Edited by Anna-Teresa Tymieniecka, https://doi.org/10.1007/978-94-017-3463-9_6. 
In Wojtyła's view, the person always transcends political and social institutions even as he needs them for the sake of his own fulfillment because only the individual subject freely acting through himself in authentic community can achieve self-possession and genuine transcendence. The person is a whole being with self-dominion, who belongs to himself (sui iuris), and who can never be reduced to a moment of the absolute totality. On the other hand, Wojtyła's philosophy conserves individuality and personal selfhood, while it simultaneously recognizes the need for universality in the form of community. Essential to Wojtyła's notion of the rational state is every individual's right to pursue happiness, always grounded in the bonum honestum, in his or her own way. ${ }^{22}$

\section{Participation-Communio Personarum}

For Wojtyła, to be social in nature means that man exists and acts "together with others." ${ }^{23}$ In his thoughts, he does not focus on society but on community. A community means something essential for its members. It is reality for getting along and common activity of people. People in a community live in mutual relationships, which enables them to differentiate between two levels of relationships: one level represents interpersonal relationships which are characterized by the "I-you" symbol and another one represents social relationships which are characterized by the "we" symbol. Both levels are parts of man's experience.

The experience with "you" is very important for "I" because on its basis "I" has richer experience of personal subjectivity. Besides, one cannot forget that "I" is "you" for another "I" which is my "you" at the same time. There are two subjects in the relationship of "I-you" with the same structure. For this reason, we use "you" and not "he." If we called the other one "he," we would take it for an object. The name "you" expresses a subject. In interpersonal relationships, there is an origin for realizing that it is not only "I" who wants to realize myself but "you" as well. There arises a duty of respect and compassion but also responsibility for another "you." 24 If one understands interpersonal relationships in this way, one can talk about communio personarum.

${ }^{22}$ Richard A. Spinello, “The Enduring Relevance of Karol Wojtyła's Philosophy," Logos. A Journal of Catholic Thought and Culture, vol. 17, no. 3 (2014): 44.

${ }^{23}$ This issue is discussed in chapter VII in The Acting Person.

24 This issue is discussed in Love and Responsibility. 
Every community of people is created through dialogue, which can take many forms. Nowadays, however, we see that the sense for dialogue is disappearing. This is reflected in the extremely high number of people who feel lonely, but also in the increase in superficial interpersonal contacts. Closely related to this is the disinterest of people about social life, which is reflected, among other things, in a lack of interest in publicly elected positions. Dialogue requires activity and humility before the truth, however, what we are witnessing is passivity as well as arrogant enforcement of selfish demands. This situation is a great challenge for education and requires an urgent solution, especially in economically developed countries, which are most affected by this social dystrophy. The loss of a sense for dialogue is based on two antagonistic anthropological concepts. On the one hand, it is individualism that closes a person to himself, and on the other hand, it is collectivism that reduces a person to an element of social structure (state, class, party, etc.).

Karol Wojtyła looks for a way out of this situation, he wants to lead out, that is, to rear up when he analyzes the problem of relationship among people and, generally, in society philosophically, while taking the person and an act fundamentally. ${ }^{25} \mathrm{He}$ considers the experience of acting with other people to be a source of knowing this dimension of man, which he calls participation (participatio) ${ }^{26} \mathrm{He}$ tries to find foundations for this fact and clarify it. In a certain sense, participation is a certain kind of dimension of a human being and his certain quality. Without this quality, man would not realize himself as a full person. Wojtyła discussed the term "communio personarum" in Gaudium et Spes (24), where he expresses interpersonal relationships between people and God and among people themselves. ${ }^{27}$ "Communio personarum" expresses a way of being and acting of people living in a community, people who are affirmed as individuals through common being and acting. Thanks to such a quality man exists and acts together with other people, whereas he loses nothing from his

${ }^{25}$ Wojtyła, The Acting Person, 262.

${ }^{26}$ Ibid., 269.

27 According to Gregory R. Beabout, The Acting Person can be interpreted as a meditation on human action inspired by the Pastoral Constitution Gaudium et Spes, which was promulgated by Paul VI as an official document of the Second Vatican Council (1965). Gregory R. Beabout, "Review Essay: Challenging the Modern World: John Paul II/Karol Wojtyła and the Development of Catholic Social Teaching by Samuel Gregg," Journal of Markets \& Morality, vol. 4, no. 2 (2001): 359, 356-362. Interestingly, this interpretation is confirmed by Wojtyła's own brief reference to the circumstances under which the book was written. He confides that while writing The Acting Person, he attended the Second Vatican Council, and recalls that his participation in the proceedings "stimulated and inspired his thinking about the person." Hans Kochler, "Karol Wojtyła's Notion of the Irreducible in Man and the Quest for a Just World Order," in Karol Wojtyta's Philosophical Legacy, ed. Nancy Mardas Billias, Agnes B. Curry, and George F. McLean (Washington D.C.: The Council for Research in Values and Philosophy, 2008), 174. 
own way of being, that is, he does not stop being a person. Participation is such a quality of the person that it realizes itself only when the person enters certain relationships with other individuals and in common good. ${ }^{28}$

Interpersonal and social relationships express what is clear to man because there are two ways by which man can realize himself and, at the same time, they emphasize the fact that man is essentially open to others, he participates in their existence. According to Wojtyła, participation must be seen as a quality of man, corresponding with his subjectivity. ${ }^{29} \mathrm{~A}$ man acting together with others, that is, participating, reveals new dimension of self as a person. ${ }^{30}$ With his being and acting together with others, he exists and acts as a person. By participating in a community, he does not stop being himself and he also does not stop fulfilling himself. Common acting without participation leaves the actions of person without their personalistic value. ${ }^{31}$

Karol Wojtyła introduces a term of personalistic norm or standard. A man is not an island ${ }^{32}$ but he realizes himself among other people without whom he would not be able to realize himself, he would not be able to realize love. Everyone forms a part of other peoples' lives. What concerns me, concerns the other as well. ${ }^{33}$ Personalistic norm relates not only to relationships with others but also to my relationship with myself and that is connected with dignity. A man cannot treat himself as a thing, he cannot subordinate higher good to lower one and live according to lower good. The first line of defense of the dignity of the person is the teaching of the whole truth about man and the appeal to the search for the full truth. For the dignity of man is in knowing and living the truth about the human good. ${ }^{34}$

Participation must be updated, it is necessary to form and shape. A man not only exists and acts with others, but he achieves his own maturity in acting and existing with others. In a certain way, a person and a community belong to each other, they are not strange to each other or antagonistic, but they form a substantial subject of existence and acting even though re-

${ }^{28}$ Ladislav Csontos, Základná antropologická línia v encyklikách Jána Pavla II (Trnava: Dobrá kniha, 1996), 70.

${ }^{29}$ Wojtyła, "Osoba: podmiot i wspólnota," 419.

30 Wojtyła, The Acting Person, 263.

31 Ibid., 273.

32 John Donne, "Meditation XVII, No Man is an Island," in Devotions upon Emergent Occasions (New York and Oxford: Oxford University Press, 1987).

33 Wojtyła, The Acting Person, 274. Cf. Marek Rembierz, "Osoba ludzka w centrum dociekań filozoficznych i teologicznych Jana Pawła," in Człowiek w refleksji Karola Wojtyly - Jana Pawła II (wybrane aspekty adekwatnej antropologii), ed. Anna Różyło and Mariusz Sztaba (Lublin: Wydawnictwo Naukowe KUL, 2014), 77-82.

${ }^{34}$ John P. Hittinger: "John Paul II on Humanae Vitae and the Priority of Ethics over Technology," Philosophy and Canon Law, vol. 5 (2019): 35-67. 
alized together with others, it is a man-person. ${ }^{35}$ Participation clarifies the term neighbour. We are invited to appreciate what is absolute in man. The term neighbour is connected to a man and a value of person alone, regardless the relationship with this or that community. It reflects humankind which belongs to every "other" man as well as "I" alone. ${ }^{36}$ The ability of every man to participate in humankind is conditioned by personalistic value of each act and by living with others. ${ }^{37} \mathrm{~A}$ man becomes a man through the deepest community.

For Wojtyła, the problem of the personal subject's relationship to the community is resolved through participation, a property or capability of the person that enables the person to engage with others without being absorbed by the social interplay and thus conditioned. If the person loses himself among others, he will be unable to freely and fully achieve himself. ${ }^{38}$ Through participation the person is able to preserve the personalistic value of actions carried out with others. This means that the human person, while being a member of different communities, can still freely determine and fulfil himself in his actions. The person chooses what is chosen by others because their choice represents a value consonant with his own values. In authentic participation, the person does not sacrifice his transcendence or suppress his personality. On the contrary, it is a neuralgic point of education.

\section{Conclusion}

Self-giving expresses a special distinguishing feature of personal existence, nature of a person. When God says that it is not good for man to be alone (cf. Gn 2,18), he confirms that the man alone does not realize this being fully. He realizes it only when he lives with somebody, and deeper and ideally, if he lives for somebody. This law for existence of a person is given as a sign of creation by the meaning of two words, alone and help, which emphasize how important a community of people for man is. Community of people means to be here for each other, in a relationship of mutual self-giving.

The man was given rule over the earth, and as God's image, he is a person able to act in a reasonable and planned manner, able to decide about himself and focus on self-realization. From the beginning, the man is called to "work."

\footnotetext{
35 Wojtyła, The Acting Person, 276.

36 Ibid., 294.

37 Ibid., 295.

38 Spinello, "The Enduring Relevance of Karol Wojtyła’s Philosophy," 40.
} 
By work, he is different from other creations. Only a man is able to work and only the man fulfils his existence on Earth by his work. In that way, work was marked by a special seal of man and humankind, the seal of a person acting in a community of people. And this seal reveals inner value and, in a certain sense, establishes its naturalness. ${ }^{39}$

Work is an occupation of each person because it belongs to a person and it completely belongs to a person who carries it out and who it is beneficial to. A man develops and fulfils himself at work and he participates in the plan of creation. John Paul II prefers subjective meaning of work to objective one. The first foundation of man's work value is a man himself - its subject. ${ }^{40}$ Although man was born to work, in the first place, work is for man and not man for work. The pope emphasises dignity of love. "Man cannot live without love. To himself, man remains an incomprehensible being and his life lacks meaning if Love is not revealed to him, if he does not meet Love." ${ }^{.41}$ A call for learning to be human in global times is a challenge to recover from love which acts not through available helping means, but through the ability to empathize and be compassionate and to give solidarity to those who suffer in such a way that this helping gesture is not perceived as humbling alms, but as brotherly concern. ${ }^{42}$

The community for Wojtyła must be an acting together-with-others and not acting only for the sake of self-serving ends. Hence, Wojtyła requires that a person in a community must have the attitude of solidarity and the attitude of opposition that paves the way for the sense of dialogue. Through these authentic attitudes, the person can participate in a community and prevent alienation. These attitudes are attainable only by a person who is receptive and humble. ${ }^{43}$ For John Paul II, solidarity was about the transmission of ideas and thus was educational.

39 John Paul II, Laborem Exercens, no. 4, http://www.vatican.va/content/john-paul-ii/en/ encyclicals/documents/hf_jp-ii_enc_14091981_laborem-exercens.html, accessed November 10, 2020.

40 John Paul II, Laborem Exercens, no. 17.

${ }^{41}$ John Paul II, Redemptor Hominis, no. 10, https://www.vatican.va/content/john-paul-ii/en/ encyclicals/documents/hf_jp-ii_enc_04031979_redemptor-hominis.html, accessed November 10, 2020 .

42 John Paul II, Apostolic Letter Novo Millenio Ineunte, 10.

${ }^{43}$ Blaise D. Ringor, "Educational Receptivity: Karol Wojtyła's Philosophy of Community as a Means Towards Embracing Differences." The European Conference on Education 2020 Official Conference Proceedings (2020): accessed November 30, 2020, http://papers.iafor.org/wp-content/ uploads/papers/ece2020/ECE2020_57552.pdf. 


\section{Bibliography}

Aguas, Jove Jim S. "Karol Wojtyła: On Person and Subjectivity. Ad Veritatem, vol. 8, no. 2 (2009): 413-454.

Apostolic Letter Novo Millennio Ineunte of his Holiness Pope John Paul II on January 6, 2001. https://www.vatican.va/content/john-paul-ii/en/apost_letters/2001/documents/hf_jpii_apl 20010106 novo-millennio-ineunte.html. Accessed November 10, 2020.

Beabout, Gregory R. "Review Essay: Challenging the Modern World: John Paul II/Karol Wojtyła and the Development of Catholic Social Teaching by Samuel Gregg." Journal of Markets \& Morality, vol. 4, no. 2 (2001): 356-362.

"Bad for business?" The Economist, February 19, 2005. https://www.economist.com/ business/2005/02/17/bad-for-business.

Buttiglione, Rocco. Karol Wojtyła: The Thought of the Man Who Became Pope John Paul II. Grand Rapids, MI: Wm. B. Eerdmans Publishing Co., 1997.

Csontos, Ladislav. Základná antropologická línia v encyklikách Jána Pavla II. Trnava: Dobrá kniha, 1996.

Donne, John. Meditation XVII, No Man is an Island. In Devotions upon Emergent Occasions. New York and Oxford: Oxford University Press, 1987.

Encyclical Letter Laborem Exercens, of his Holiness Pope John Paul II on September 14, 1981. http://www.vatican.va/content/john-paul-ii/en/encyclicals/documents/hf_jp-ii_enc_14091981 laborem-exercens.html. Accessed November 10, 2020.

Encyclical Letter Redemptor Hominis, of his Holiness Pope John Paul II on March 4, 1979. https:// www.vatican.va/content/john-paul-ii/en/encyclicals/documents/hf_jp-ii_enc_04031979_ redemptor-hominis.html. Accessed November 10, 2020.

Franz Franks, Angela. "Thinking the Embodied Person with Karol Wojtyła." Nova et Vetera, English Edition, vol. 16, no. 1 (2018): 141-171.

Górzna, Sylwia. "Martin Buber: Father of the Philosophy of Dialogue." European Journal of Science and Theology, vol. 10, no. 5 (2014): 45-53.

Hittinger, John P. "John Paul II on Humanae Vitae and the Priority of Ethics over Technology." Philosophy and Canon Law, vol. 5 (2019): 35-67.

Köchler, Hans. "Karol Wojtyła's Notion of the Irreducible in Man and the Quest for a Just World Order." In Karol Wojtyła's Philosophical Legacy, edited by Nancy Mardas Billias, Agnes B. Curry, and George F. McLean, 165-182. Washington D.C.: The Council for Research in Values and Philosophy, 2008.

Köchler, Hans. "The Phenomenology of Karol Wojtyła. On the Problem of the Phenomenological Foundation of Anthropology." Philosophy and Phenomenological Research, vol. 42 (1982): 326-334.

Merecki, Jarosław. Osoba i dobro. Szkice o filozofii i teologii osoby Karola Wojtyly - Jana Pavla II. Lublin: Wydawnictwo KUL, 2019.

Palouš, Radim. K filozofii výchovy. Praha: SPN, 1991.

Pastoral Constitution on the Church in the Modern World Gaudium et Spes, promulgated by His Holiness Pope Paul VI on December 7, 1965. http://www.vatican.va/archive/hist_councils/ ii_vatican_council/documents/vat-ii_const_19651207_gaudium-et-spes_en.html. Accessed November 15, 2016.

Rembierz, Marek. "Osoba ludzka w centrum dociekań filozoficznych i teologicznych Jana Pawła." In Człowiek w refleksji Karola Wojtyly - Jana Pawła II (wybrane aspekty adekwatnej antropologii), edited by Anna Różyło and Mariusz Sztaba, 77-82. Lublin: Wydawnictwo Naukowe KUL, 2014. 
Ringor, Blaise D. “Educational Receptivity: Karol Wojtyła's Philosophy of Community as a Means Towards Embracing Differences. The European Conference on Education 2020 Official Conference Proceedings (2020). Accessed November 30, 2020. http://papers.iafor.org/wpcontent/uploads/papers/ece2020/ECE2020_57552.pdf.

Spinello, Richard A. "The Enduring Relevance of Karol Wojtyła's Philosophy." Logos. A Journal of Catholic Thought and Culture, vol. 17, no. 3 (2014): 17-48.

Styczeń, Tadeusz. "Być sobą to przekraczać siebie. O antropologii Karola Wojtyły." In Osoba i czyn oraz inne studia antropologiczne, Karol Wojtyła, 491-526. Lublin: TN KUL, 1994.

Taylor, Charles. Sources of the Self: The Making of Modern Identity. Cambridge, MA: Harvard University Press, 1992.

Taylor, Charles. The Ethics of Authenticity. Cambridge, MA: Harvard University Press, 1992.

Valčo, Michal. "Veda vs. scientizmus: kritické postrehy." In Disputationes Quodlibetales XXII. Racionalita a viera, edited by Pavol Dancák and Radovan Šoltés, 19-33. Prešov: Gréckokatolícka teologická fakulta, 2019.

Wilder, Alfred. "Community of Person in the Thought of Karol Wojtyła." Angelicum, vol. 56 (1979): 211-244.

Wojtyła, Karol. "Participation or Alienation?” In The Self and the Other. Analecta Husserliana. The Yearbook of Phenomenological Research, edited by Anna-Teresa Tymieniecka, vol 6. 1977, Springer, Dordrecht. https://doi.org/10.1007/978-94-017-3463-9_6.

Wojtyła, Karol. The Acting Person. Translated by Andrej Potocki. Dordrecht: D. Reidel Publishing Company, 1979.

Wojtyła, Karol. "The Person: Subject and Community," in The Review of Metaphysics, vol. 33, no. 2 (December 1979), 273-308.

Wojtyła Karol. "Subjectivity and the Irreducible in Man." In Analecta Husserliana. The Yearbook of Phenomenological Research, edited by Anna-Teresa Tymieniecka 1978, vol, VII, Reidel Publ., 107-114.

Pavol Dancák

\author{
Riflessione contemporanea sulla partecipazione \\ come dimensione essenziale della filosofia dell'educazione \\ nel contesto di Persona e atto
}

\begin{abstract}
Sommario
L'articolo affronta il tema dell'idea di partecipazione come dimensione essenziale della filosofia dell'educazione nel contesto del pensiero di Karol Wojtyła. L'autore presenta i concetti di persona e di partecipazione e incoraggia una discussione sulla filosofia dell'educazione, perché nota che la libertà dell'individuo è trattata in modo estremamente individualistico. Wojtyła si riferisce alla filosofia della coscienza e alla filosofia dell'essere per considerare la costituzione delle nostre idee in modo appropriato per educarci a stare insieme con tutte le persone e le creature, con l'intero universo, il che di fatto, ci dà un senso del proprio posto.

Parole chiave: individualismo, persona, partecipazione, solidarietà, educazione
\end{abstract}


Pavol Dancák

\author{
Réflexion contemporaine sur la participation \\ comme dimension essentielle de la philosophie de l'éducation \\ dans le cadre de Personne et acte
}

\begin{abstract}
Résumé
L'article aborde la question de l'idée de participation comme dimension essentielle de la philosophie de l'éducation dans le contexte de la pensée de Karol Wojtyła. L'auteur présente les concepts de personne et de participation et encourage une discussion sur la philosophie de l'éducation, car il constate que la liberté de l'individu est traitée de manière extrêmement individualiste. Wojtyła fait référence à la philosophie de la conscience et à la philosophie de l'être pour considérer la constitution de nos idées d'une manière appropriée pour nous éduquer à être ensemble avec toutes les personnes et toutes les créatures, avec l'univers entier, ce qui nous donne en fait un sens de notre propre place.
\end{abstract}

Mots-clés: individualisme, personne, participation, solidarité, éducation 